Article

VASILEVA, V. ${ }^{1 *}$ ATHAR, M. ${ }^{2}$

\section{Studies on Nodulating Capacity of Some Forage Legumes Grown AlONe or in MiXTURES}

\author{
Estudos sobre a Capacidade de Nodulação de Leguminosas Forrageiras \\ Cultivadas Isoladas ou em Combinação
}

\begin{abstract}
A pot experiment was conducted to study the nodulating capacity of some forage legumes. Birdsfoot trefoil (Lotus corniculatus L), sainfoin (Onobrychis viciifolia Scop.) and subterranean clover (Trifolium subterraneum L.) were grown in pure culture (100\%) and in mixtures with tall fescue (Festuca arundinacea Schreb.) in the ratios: birdsfoot trefoil + tall fescue (50:50\%); sainfoin + tall fescue (50:50\%); subterranean clover + tall fescue $(50: 50 \%)$; birdsfoot trefoil + subterranean clover + tall fescue (33:33:33\%); sainfoin + subterranean clover + tall fescue (33:33:33\%). Birdsfoot trefoil from the crops cultivated in pure stands showed the highest nodulation rating (31), followed by sainfoin (26) and subterranean clover (26). Nodulation rating in binary mixtures with grass component increased to $16.1 \%$ for birdsfoot trefoil and to $23.1 \%$ for subclover. Birdsfoot trefoil, both in pure stands and in mixtures, showed the highest phosphorus use efficiency for nodule formation.
\end{abstract}

Keywords: phosphorus use efficiency, subterranean clover, sainfoin, subterranean clover, tall fescue, pure and mixed culture

RESUMO - Foi realizada uma experiência em vasos para estudar a capacidade de nodulação de algumas espécies de leguminosas forrageiras. O cornichão (Lotus corniculatus L.), o sanfeno (Onobrychis viciifolia Scop.) e o trevo-subterrâneo (Trifolium subterraneum L.) foram cultivados em cultura isolada (100\%) e em combinação com a festuca-alta (Festuca arundinacea Schreb.) nas seguintes proporções: cornichão + festuca-alta (50:50\%); sanfeno + festuca-alta (50:50\%); trevo-subterrâneo + festuca-alta (50:50\%); cornichão + trevo-subterrâneo + festuca-alta (33:33:33\%); sanfeno + trevo-subterrâneo + festuca-alta (33:33:33\%). Nas culturas cultivadas isoladamente, o cornichão apresentou o maior indice de nodulação (31), seguido pelo sanfeno (26) e pelo trevo-subterrâneo (26). O indice de nodulação nas misturas binárias com gramíneas teve aumento de 16,1\% para o cornichão e de 23,1\% para o trevo-subterrâneo. O cornichão, isolado e em combinação, apresentou a maior eficiência do uso de fósforo para a formação de nódulos.

Palavras-chave: eficiência do uso de fósforo, sanfeno, trevo-subterrâneo, festucaalta, cultivo isolado ou em combinação.

Copyright: This is an open-access article distributed under the terms of the Creative Commons Attribution License, which permits unrestricted use, distribution, and reproduction in any medium, provided that the original author and source are credited.

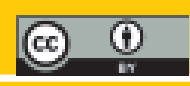

\title{
INTRODUCTION
}

Legumes are an important component of ecology-friendly forage systems because they allow obtaining high yields using less nitrogen fertilizer. As a result of their nitrogen-fixing ability, legumes can be used as an alternative to

1 Institute of Forage Crops, 89 “General Vladimir Vazov” Str., 5800 Pleven, Bulgaria; ${ }^{2}$ Department of Botany, University of Karachi, Karachi-70275. 
industrial nitrogen fertilizers and foster environmental protection. Often, legumes are grown in mixtures with grasses. The advantage of grass-legume mixtures is the ability to supply the grass component with nitrogen through symbiotic nitrogen fixation. Nitrogen produced by this process is a key element of sustainable agriculture (Luscher et al., 2014). In mixtures, the amount of nitrogen decreases, legumes receive more nitrogen from the air and they are less competitive with grasses for soil nitrogen. On the other hand, in the appropriate proportions with grass components, legumes are stimulated to fix more nitrogen.

Nodulation and nitrogen fixation are highly variable and related to the share of legumes in the mixtures, as well as environmental conditions (Karmakar et al., 2015). Many factors influence nodulation, but phosphorus has a major role because of its importance in the formation of the root system (Jing-Wei Fan, 2015). This element plays a key role in the number, size and activity of nodules. The ample supply of phosphorus increases the longevity of the nodule.

Climate changes force forage crops and mixtures to adapt to the altered conditions. Legumes species that can provide self-sowing and persist continuously in the sward become of practical importance. Subterranean clover (Trifolium subterraneum L.) as nitrogen fixing species is widely distributed in pastures of temperate climatic regions of Middle and Northern Europe, and America (Nichols et al., 2012; Lucas et al., 2015). In Bulgaria, investigations on subterranean clover as a component of sown pasture in recent years have shown that it has practical application for local climatic conditions (Ilieva et al., 2015).

In this work, some parameters relative to nodulating ability of birdsfoot trefoil, sainfoin and subterranean clover, grown alone and in mixtures with tall fescue, were studied.

\section{MATERIAL AND METHODS}

The pot experiment was carried out in the greenhouse under semi-controlled conditions. Birdsfoot trefoil, cv. "Targovishte 1"; sainfoin, local population; subterranean clover, cv. "Antas" and tall fescue, cv. "Albena" were used. Plants were grown in pure stands $(100 \%)$ and in mixtures in the following ratios: birdsfoot trefoil + tall fescue (50:50\%), sainfoin + tall fescue (50:50\%), subterranean clover + tall fescue $(50: 50 \%)$, birdsfoot trefoil + subterranean clover + tall fescue (33:33:33\%), sainfoin + subterranean clover + tall fescue $(33: 33: 33 \%)$.

Plastic pots with capacity of $6 \mathrm{~L}$ were used, filled with soil (leached chernozem subtype) with four replications of each treatment. Seed were sown at the depth of 1-1.5 cm for birdsfoot trefoil and subterranean clover, $3 \mathrm{~cm}$ for sainfoin, and $0.5-1 \mathrm{~cm}$ for tall fescue. Water soluble phosphorus fertilizer $\left(2.62 \mathrm{~g} \mathrm{pot}^{-1}\right)$ was added once.

Two harvests for forage were made and plants were uprooted and washed with tap water; the number of nodules per plant was recorded as well distribution of nodules on the roots (central, lateral roots). Dry root biomass $\left(\mathrm{g} \mathrm{pot}^{-1}\right)$ (dried at $60{ }^{\mathrm{I}} \mathrm{C}$ ) was recorded. Nodulation rating (according to Somasegaran and Honen, 1994); phosphorus use efficiency for dry root mass formation (PUE $\mathrm{DRM})(\mathrm{g} / \mathrm{g})$ = dry mass $(\mathrm{g}) /$ phosphorus applied (g); phosphorus use efficiency for nodule formation (PUE Nodules) $(\mathrm{g} / \mathrm{g})=$ nodule biomass $(\mathrm{g}) /$ phosphorus applied $(\mathrm{g})$, (formulae of Bowen and Zapata, 1991). The values of these parameters were compared to those of legumes grown in pure stands, and data were averaged for both experimental years and statistically processed using the software SPSS (2012).

\section{RESULTS AND DISCUSSION}

In our study, nodulation rating of legume crops grown alone and in mixtures did not differ significantly. The highest nodulation rating was found for birdsfoot trefoil (31) and the same level rank was recorded for both sainfoin (26) and subterranean clover (26) (Figure 1).

The nitrogen fixation process is related to efficiency in nodulation. Symbiotic nitrogen fixation takes place in highly differentiated nodules formed after the interaction of Rhizobia with the host plant (Serraj et al., 1999). The duration of their life cycle is essential for the normal functioning and it varies depending on various factors (Milev, 2014; Jing-Wei Fan, 2015). 


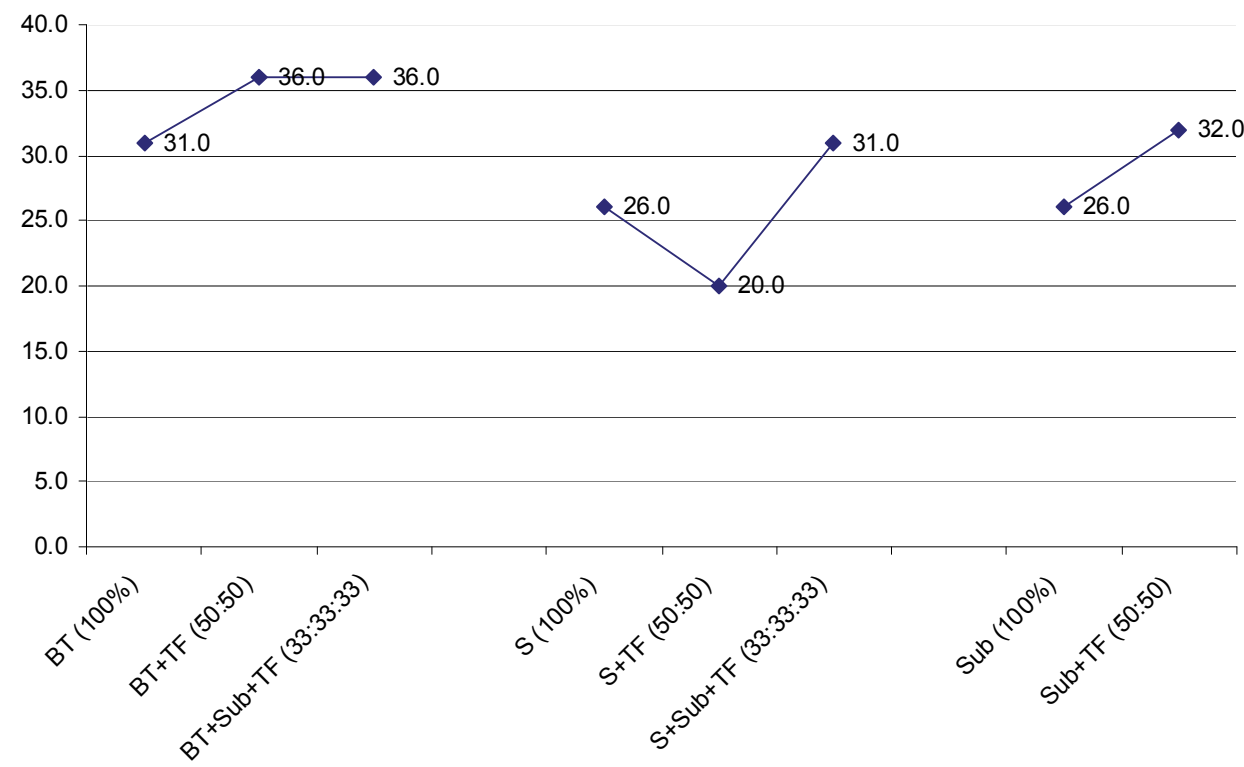

(BT - birdsfoot trefoil, TF - tall fescue, Sub - subterranean clover, $\mathrm{S}$ - sainfoin); $\mathrm{SE}(\mathrm{P}=0.05)=1.93 ; \pm \mathrm{SD}=5.47$.

Figure 1 - Nodulation rating of some legumes grown alone and in mixtures.

In birdsfoot trefoil grown alone, the amount of plants whose nodules were distributed on the main lateral roots was similar to those whose nodules were distributed on the main root (40\%) (Figure 2). Nodules distributed on the main root are an indication of their effectiveness in terms of nitrogen fixation (Athar and Shabbir, 1997). The nodulation rating in mixtures was found to be higher $-16.1 \%$ for the mixtures of birdsfoot trefoil to $23.1 \%$ for those of subterranean clover.

In the mixtures of birdsfoot trefoil (two components mixtures with tall fescue and three components mixtures with subterranean clover and tall fescue), the proportion of plants with nodules distributed to the main roots increased to $60 \%$. All birdsfoot trefoil plants (alone and in mixtures grown) nodulated (100\%).

In sainfoin and subterranean clover grown alone, the nodulation rating had the same values. However, in sainfoin, there were plants without nodules. For sainfoin grown in pure stands, the percentage of plants without nodules was 20 and twice as much in mixtures with tall fescue, where nodulation rating was strongly depressed (by 23.1\%). It is assumed that this is due to competition for absorption of some nutrients as well to the allelopathic effect of grass components found by Siegel and Bush (1997) and Renne et al. (2004). In the three component mixtures (with subterranean clover as a component), nodulation rating was recovered and was found to be higher than that of sainfoin grown alone (by 19.2\%), without nodule-forming plants.

Nodulation rating of subterranean clover in mixtures with tall fescue was over $20 \%$ higher because of the positive relationships between these species. Nodulation in legumes was influenced by many factors; one of them was phosphorus content. Phosphorus use efficiency is an agronomic parameter which represents the ratio between productivity and amount of phosphorus applied. It would be interesting to assess phosphorus use efficiency when legumes and grasses are grown alone and in mixtures, knowing that efficiency of resource use in mixtures is greater (Albayrak et al., 2011; Kusvuran et al., 2014).

In our study, we estimated phosphorus use efficiency for dry root mass productivity (PUE DRM) and for nodule formation (PUE Nodules) (Figure 3). Phosphorus use efficiency, for dry root mass formation in crops grown in pure stands, was found to be (PUE DRM) $=1.164$ in sainfoin, $($ PUE DRM $)=0.721$ in birdsfoot trefoil and $($ PUE DRM $)=0.282$ in subterranean clover.

In birdsfoot trefoil, phosphorus use efficiency for dry root mass formation in mixtures was higher as compared to PUE in pure birdsfoot trefoil. Differences were similar for the two component mixtures with tall fescue $(36.6 \%)$ and for the three component mixtures with subterranean clover and tall fescue (37.9\%). 


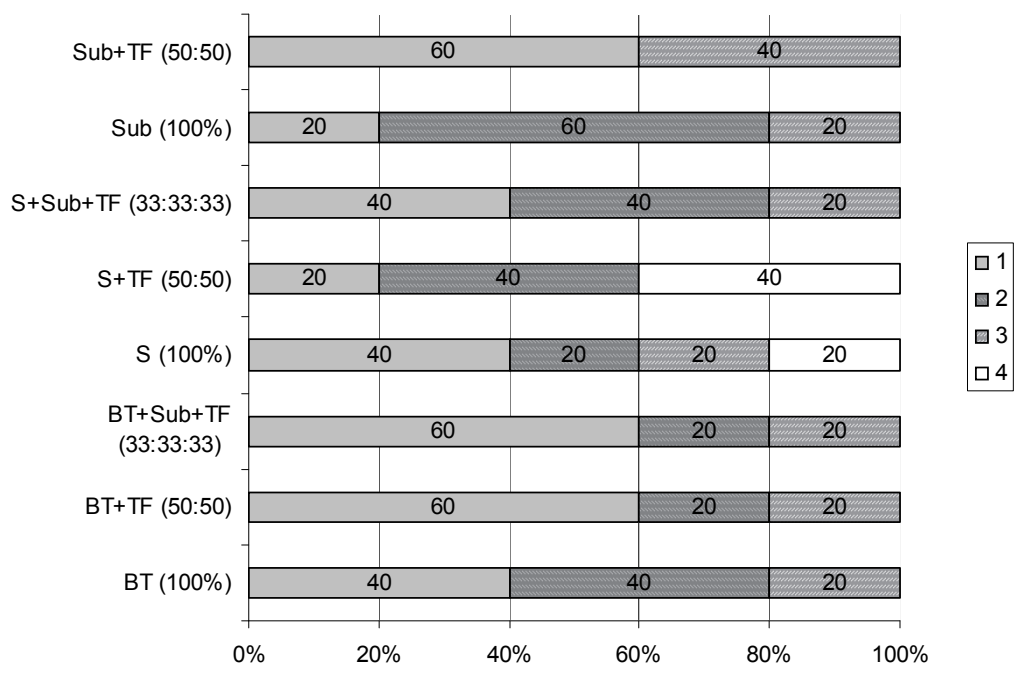

${ }^{1}$ Plants with nodules distributed on the main root $\mathrm{SE}(\mathrm{p}=0.05)=6, \pm \mathrm{SD}=16 ;{ }^{2}$ plants with nodules distributed on the lateral roots, but closer to the main root $(\mathrm{p}=0.05)=6, \pm \mathrm{SD}=18 ;{ }^{3}$ plants whose nodule distribution was dispersed on the roots $\mathrm{SE}(\mathrm{p}=0.05)=4, \pm \mathrm{SD}=10 ;{ }^{4} \mathrm{plants}$ without nodules $\mathrm{SE}(\mathrm{p}=0.05)=5, \pm \mathrm{SD}=14$.

Figure 2 - Distribution of nodules on the root system of some forage legumes grown pure and in mixtures.

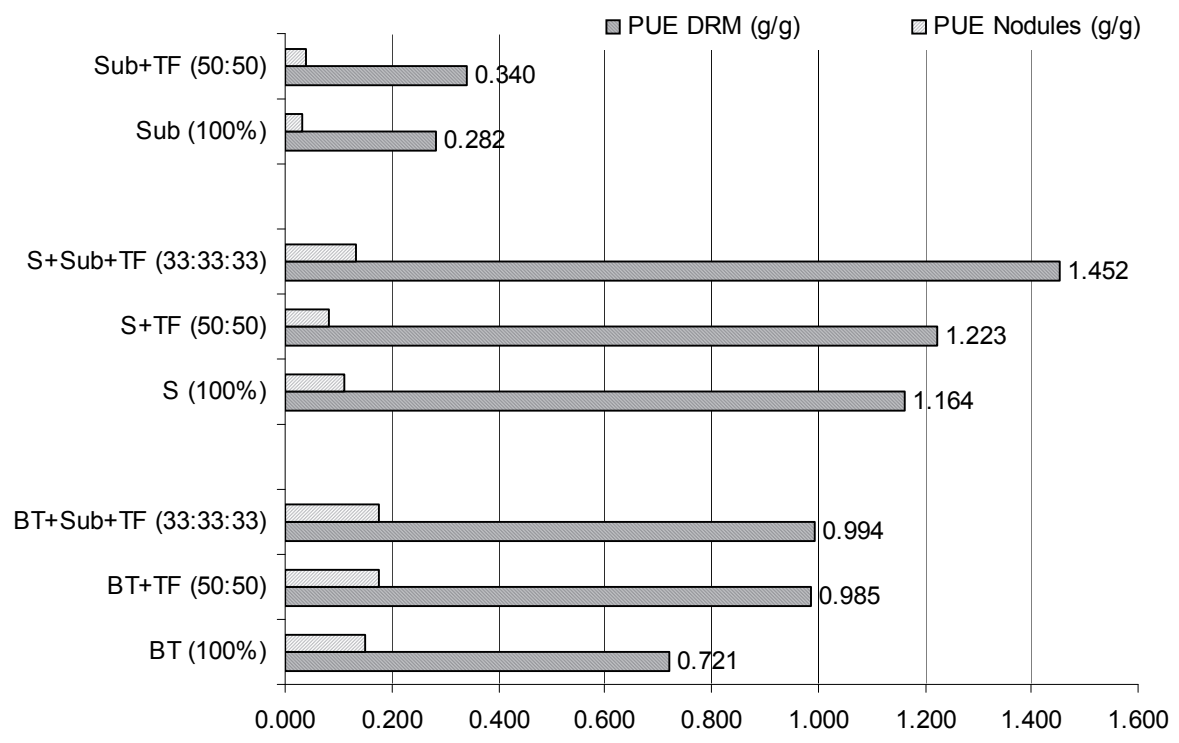

PUE DRM SE $(\mathrm{p}=0.05)=0.14, \pm \mathrm{SD}=0.41 ;$ PUE Nodules $\mathrm{SE}(\mathrm{p}=0.05)=0.19, \pm \mathrm{SD}=0.56$.

Figure 3 - Phosphorus use efficiency for dry root mass formation (PUE DRM) and nodule formation (PUE Nodules) of birdsfoot trefoil, sainfoin and subterranean clover, grown pure and in mixtures.

The values of this index are associated with root mass productivity. In mixtures of sainfoin with tall fescue, phosphorus use efficiency was slightly higher than that of pure grown sainfoin. Some authors (Thorsted et al., 2006) believe that competition for water, light and other factors in mixed systems could have a negative effect on productivity. The productivity of mixtures largely depends on the compatibility of species involved (Chourkova, 2007).

In mixed cropping interspecific competition, the growth and development of one species is decreased (Zhang and Li, 2003; Marty et al., 2009; Vasileva et al., 2017), as we assume it is the case between sainfoin and tall fescue. Hardarson and Atkins (2003) consider that the main factor for plant biomass formation in sainfoin is nitrogen from the soil and from biological nitrogen fixation. This plant, however, typically fixes relatively small amounts of nitrogen from the 
atmosphere; this was observed while conducting studies by different methods - the isotopic $\mathrm{N}^{15}$ method (Prosser et al., 2006), as well as the reference culture method (Carlsson and HussDanell, 2003). Compared to other legumes (white clover, red clover and alfalfa), the authors measured lower amounts of fixed nitrogen. As a possible reason, they point to the fact that sainfoin needs twice as much the amount of $\mathrm{CO}_{2}$ for $1 \mathrm{~mol} \mathrm{~N}_{2}$ compared to other legumes included in the study.

Sainfoin has less ability to absorb carbon as well smaller leaf surface, which affected the nodulation and nitrogen fixation processes (Shakirov et al., 2010).

In three component mixtures of sainfoin with subterranean clover and tall fescue, the phosphorus use efficiency was higher by $24.8 \%$ compared to the pure sainfoin.

Subterranean clover in mixtures with tall fescue showed more than $20 \%$ higher phosphorus use efficiency for root mass formation.

Thus, in mixtures with tall fescue, phosphorus use efficiency for forming the root mass was greater by $20.5 \%$ for subterranean clover and more than $30 \%$ for birdsfoot trefoil.

In terms of phosphorus use efficiency for nodule formation, birdsfoot trefoil from the pure crops showed the highest phosphorus use efficiency (PUE Nodules) $=0.152$, followed by sainfoin $($ PUE Nodules $)=0.122$ and subterranean clover $(\mathrm{PUE}$ Nodules $)=0.034$. In mixtures, except for those of sainfoin with tall fescue, phosphorus use efficiency for the mixtures of birdsfoot trefoil and subterranean was higher by over $16 \%$.

Birdsfoot trefoil used the rational phosphorus in the mixtures for dry root mass and nodules formation.

The nodulation rating of legume species grown in pure stands was found to be as follows: birdsfoot trefoil (31), sainfoin (26) and subterranean clover (26). When the grass component was tall fescue to birdsfoot trefoil, sainfoin and subterranean clover, the nodulation rating in binary mixtures increased to $16.1 \%$ for birdsfoot trefoil and to $23.1 \%$ for subterranean clover. Sainfoin showed less nodulation: $20 \%$ of pure plants do not form nodules and $40 \%$ of the plants in mixtures with tall fescue. Birdsfoot trefoil, both pure and in mixtures, showed the highest phosphorus use efficiency for dry root mass and nodule formation. In mixtures with tall fescue, phosphorus use efficiency was higher by more than $30 \%$ for root mass formation and more than $15 \%$ for nodule formation.

\section{REFERENCES}

Albayrak S. et al. Forage yield and the quality of perennial legume-grass mixtures under rainfed conditions. Not Bot Hortic Agrobot Cluj-Napoca. 2011;39:114-8.

Athar M., Shabbir S.M. Nodulation characteristics of some of the forage and browse legumes. Phytologia. 1997;82:12-9.

Bowen G.D., Zapata F. Efficiency in uptake and use of N by plants. In: Proceeding Series Stable Isotopes in Plant Nutrition Soil Fertility and Environmental Studies, IAEASM 313/130. Vienna: 1991. p.349-62.

Carlsson G., Huss-Danell K. Nitrogen fixation in perennial forage legumes in the field. Plant Soil. 2003;2:353-72.

Chourkova B. Botanical composition and productivity of birdsfoot trefoil in mixtures with Meadow Grasses in Bulgaria. $\mathbf{J}$ Balkan Ecol. 2007;10:57-61.

Hardarson G., Atkins G. Optimizing biological $\mathrm{N}_{2}$ fixation by legumes in farming system. Plant Soil. 2003;1:41-54.

Ilieva A., Vasileva V., Katova A. The effect of mixed planting of birdsfoot trefoil, sainfoin, subterranean clover, and tal fescue on nodulation, and nitrate reductase activivity in shoots. J Global Agric Ecol. 2015;4:222-8.

Jing-Wei Fan et al. Changes in root morphology and physiology to limited phosphorus and moisture in a locally-selected cultivar and an introduced cultivar of Medicago sativa L. growing in alkaline soil. Plant Soil. 2015;392:215-26. 
Karmakar R. et al. Legume-rhizobia symbiosis under stress. In: Arora N.K., editor. Plant microbe-symbiosis: applied facets. London: Springer, 2015. p.241-58.

Kusvuran A., Ralice Y., Saglamtimur T. Determining the biomass production capacities of certain forage grasses and legumes and their mixtures under mediterranean regional conditions. Acta Adv Agric Sci. 2014;2:13-24.

Lucas R.J.et al. Selection of sub clover cultivars for New Zealand dryland pastures. J New Zealand Grass. 2015;77:203-10.

Luscher A al et. Potential of legume-based grassland-livestock systems in Europe: a review. Grass Forage Sci. 2014;69:206-28.

Marty C. et al. Complex interactions between a legume and two grasses a subalpine meadow. Am J Bot. 2009;96:1814-20.

Milev G. Effect of Foliar Fertilization on Nodulation and Grain Yield of Pea (Pisum sativum L.). Turkish J Agric Nat Sci. 2014;1:668-72. (Special Issue)

Nichols P.G.H. et al. Temperate pasture legumes in Australia - their history, current use and future prospects. Crop Past Sci. 2012;63:691-725.

Prosser J., Rangel-Castro J.I., Killham K. Studying plant-microbe interactions using stable isotope technologies. Cur Opinion Biotechnol. 2006;17:98-102.

Renne I.J.et al. Low allelopathic potential of an invasive forage grass on native grassland plants: a cause for encouragement. Basic Appl Ecol. 2004;5:261-9.

Serraj R., Sinclair T., Purcell L. Symbiotic N2 fixation response to drought. J Exp Bot. 1999;50:143-55.

Shakirov Z. et al. Nodulation in onobrychis perennial legume plants. Am J Plant Sci. 2010;1:119-30.

Siegel M.R., Bush L.P. Toxin production in grass/endophyte associations. Plant Relat. 1997;5:185-207.

Somasegaran P., Honen H.Z. Handbook of Rhizobium: methods in legume-rhizobium technology. New York: Springer, 1994.

SPSS 2012. SPSS Version 20.0. SPSS Inc. 233 S. Chicago: Wacker Drive Chicago, 2012.

Thorsted M.D., Weiner J., Olesen J.E. Above and below-ground competition between intercropped winter wheat Triticum aestivum and white clover Trifolium repens. J Appl Ecol. 2006;43:237-45.

Vasileva V., Mitova T., Athar M. Enhancement of biomass production of birdsfoot trefoil, sainfoin and subterranean clover by mixed cropping with perennial ryegrass. Pak J Bot. 2017;49:115-8.

Zhang F., Li L. Using competitive and facilitative interactions in intercropping system enhances crop productivity and nutrientuse efficiency. Plant Soil. 2003;248:305-12. 